\title{
Endometrial biopsies of old mares - What to expect?!
}

\author{
Julia Kabisch, Kristin Klose and Heinz-Adolf Schoon \\ Institute of Pathology, Faculty of Veterinary Medicine, University of Leipzig, Germany
}

\begin{abstract}
Summary: Based on the ageing of the equine population, the number of old mares presented for breeding will also increase. However, aged mares frequently exhibit fertility problems. The objective of this study was a detailed histomorphological characterisation of endometrial biopsies of old mares to identify causes for their reduced fertility. For this purpose 819 endometrial biopsies of 814 old mares (minimum age: 20 years) submitted to the Institute of Pathology (Faculty of Veterinary Medicine, University of Leipzig) between 1993 and 2014 and the related anamnestic data were evaluated retrospectively. The study comprised a detailed histomorphological characterisation of endometrial alterations by haemalaun and eosin (H.E.) stain, the categorisation of the cases according to Kenney and Doig (1986) without or in consideration of the duration of barrenness and, for some randomly selected samples $(n=157)$, an assessment by Picro-Sirius Red stain for further investigation of degenerative angiopathies. Most of the cases were assigned to categories IIb and III (83\%) without consideration of the duration of barrenness or category III (68\%) in consideration of the duration of barrenness. The categorisation of the cases was based on the occurrence of endometrosis and, to a lesser extent, endometritis. In contrast, an endometrial atrophy or lymphatic lacunae were not observed in any sample. Nearly all biopsies (97\%) showed endometrosis which was mostly moderate. Endometritis was diagnosed in $49 \%$ of all samples. The inflammation was predominantly mild and non-suppurative (subclinical). Histopathological findings which are not considered in the categorisation system of Kenney and Doig (1986) were frequently detected. This comprised degenerative lesions of blood vessels (angiosclerosis; $89 \%$ of all samples; mostly moderate to severe), periglandular accentuated mononuclear inflammatory cell infiltrates (PAMC; $58 \%$ of all samples; mostly mild), perivasculitis (43\% of all samples; mostly mild) and $16 \%$ of all samples showed signs of endometrial maldifferentiation. The endometrium of old mares predominantly exhibited a mixture of endometrial alterations: mostly marked degenerative lesions (endometrosis and angiosclerosis), predominantly mild inflammatory processes (endometritis, PAMC and perivasculitis) and, to a lesser extent, functional disturbances. These findings are only partially considered in the evaluation scheme of Kenney and Doig (1986). However, histopathological findings which were left out of the categorisation scheme so far (e.g. angiosclerosis and other functional disorders than endometrial atrophy) also directly or at least indirectly influence the fertility of a mare. Therefore, these findings as well as the age of the mare have also to be evaluated for a precise prediction of the reproductive potential of the old mare. In any case the endometrial biopsy can be helpful for the owner or the veterinarian to decide whether breeding an old mare is an acceptable risk, especially in mares whose reproduction potential is completely unknown (aged maiden mares and mares with the last foaling a long time ago).
\end{abstract}

Keywords: reproduction, old mares, endometrial biopsy, subfertility, categorisation, age

Citation: Kabisch J., Klose K., Schoon H.-A. (2019) Endometrial biopsies of old mares - What to expect?! Pferdeheilkunde 35, 21 1-219; DOI 10.21836/PEM20190302

Correspondence: Julia Kabisch, University of Leipzig, Faculty of Veterinary Medicine, Institute of Pathology, An den Tierkliniken 33,04103 Leipzig, Germany; julia.kabisch@vetmed.uni-leipzig.de

Received: February 20, 2019 | Accepted: March 4, 2019

\section{Introduction}

Geriatric horses represent a significant share of the equine population and their number seems to increase further (Mellor et al. 1999, Brosnahan and Paradis 2003, Cole et al. 2005, USDA 2007, McGowan et al. 2010a, 2010b, Ireland et al. 2011, USDA 2016). In contrast to women (Gindoff and Jewelewicz 1986, te Velde and Pearson 2002, Videan et al. 2008), mares are able to reproduce despite advanced age (McCue 1991, Horohov et al. 2002, Traub-Dargatz et al. 2006, Burns 2016). Therefore, the number of old mares presented for breeding and reproductive management by veterinarians will also increase (Burns 2016). However, with increasing age reproductive potential declines in mares (Gordon and Sartin 1978, McCue 1991, Ginther 1992, Vanderwall et al. 1993, Kriesten 1995, Heilkenbrinker et al. 1997, Schoon et al. 1997b, Schoon and Schoon 2003, Carnevale 2006, Scoggin 2015). The causes for this association between increasing age and decline in fertility are numerous and multifactorial (Scoggin 2015) but uterine pathology has been implicated as a major cause of age-associated subfertility
(Carnevale 2006). Besides the age of the mare, the number of foalings also has an effect on the occurrence of endometrial alterations and both factors do not cause the same lesions (Bracher et al. 1997a). Fertility problems are common in old mares and therefore breeding an aged mare is often challenging (King 1999, Pycock 2003, Smith Thomas 2007). As a consequence, these animals should be evaluated carefully before breeding (Carnevale 2006). In this context the uterine biopsy can be useful to predict the ability of the mare to carry a foal to term and therefore can help the owner to determine whether breeding the mare is an acceptable risk (Carnevale 2006). The categorisation system of Kenney and Doig (1986) is accepted internationally for predicting the expected foaling rate of a mare based on histopathological findings and the duration of barrenness. However, certain factors affecting the reproductive potential (the age of the mare, endometrial alterations such as angiosclerosis) are not considered (Schoon et al. 1997b, 1997c, Schoon and Schoon 2003).

The aim of this study was a detailed histomorphological characterisation of endometrial biopsies of old mares and categorisa- 
tion according to the system of Kenney and Doig (1986). Furthermore, correlations among the histopathological findings and the anamnestic data should be demonstrated. Finally, the causes for sub-/infertility in old mares and the usefulness of the endometrial biopsy in this context should be pointed out.

\section{Material and Methods}

819 endometrial biopsies and related anamnestic data of 814 old mares (minimum age: 20 years) were analysed retrospectively. All samples were submitted to the Institute of Pathology (Faculty of Veterinary Medicine, University of Leipzig) between 1993 and 2014 for routine examination. The fixed tissue specimens were embedded in paraplast using an automatic processor (Hypercenter XP, Shandon, Frankfurt, Germany), sectioned at 3-4 $\mu \mathrm{m}$ thickness and stained with haemalaun and eosin (H.E.). All samples were characterised histomorphologically in detail with regard to inflammatory processes (endometritis, periglandular accentuated mononuclear inflammatory cell infiltrates (PAMC), ((peri-)vasculitis), degenerative lesions (endometrosis, angiosclerosis, lymphatic lacunae) and functional disturbances (irregular endometrial differentiation (ID), unequal endometrial differentiation (UD), endometrial atrophy, endometrial inactivity during the breeding season). Additionally, 157 samples with angiosclerosis were selected randomly for further investigation of degenerative angiopathies by Picro-Sirius Red stain. Finally, endometrial biopsies were graded according to the categorisation system of Kenney and Doig (1986) in/without consideration of the duration of barrenness of the mare. The statistical evaluation of the data was performed using the software "IBM SPPS Statistics 25®". The Chi-Quadrat-Test according to Pearson and the Fisher's exact-test were applied to determine a significant coherence. A p-value $\leq 0.05$ was consistent with a statistically significant result.

\section{Results}

\section{General characteristics of the examined geriatric mares}

The average age of the animals was 21.4 years, the oldest mare was 32 years old. However, $93 \%$ of all mares were younger than 25 years. For 429 mares (53\%) details about the reproductive status (number of foalings) were available. $8 \%$ of the horses had never given birth to a foal and $12 \%$ of the horses only had foaled one time, respectively. The other mares (80\%) had produced at least 2 foals in their life time with a maximum of 20 offspring. The duration of barrenness was known for 622 mares (76\%). Only $6 \%$ were not barren at the time of sample collection. The vast majority of the individvals (94\%) had been unsuccessfully bred in the past whereby $59 \%$ of the mares had been barren for at least 2 years.

\section{Categorisation according to Kenney and Doig (1986)}

The results of categorisation without consideration (blue bars) and in consideration (red bars) of the duration of barrenness of the mare is provided in Fig. 1.
A categorisation exclusively based on the histopathological findings without consideration of the time of barrenness was achievable for 816 samples. In 3 of the 819 samples the occurrence of endometritis and/or endometrosis (criteria of the categorisation system) could not definitely be assessed due to widespread artefacts. As shown in Fig. 1, approx. a similar percentage of biopsies (40\% and $43 \%$, respectively) was classified both to category IIb and III. Category Ila was less frequently diagnosed (15\%) and only $2 \%$ of the samples were assigned to category 1 .

The duration of barrenness of the mare was known in 625 cases. Therefore, in these cases, the categorisation was performed in consideration of the length of barrenness. More than $2 / 3$ of the samples (68\%) were assigned to category III. Category Ilb was diagnosed in $24 \%$ of all cases while categories $I$ la and I were rarely diagnosed $(6 \%$ and $2 \%$, respectively).

\section{Histopathological findings}

The biopsy specimens showed a variety of histopathological findings (inflammatory processes, degenerative lesions and functional disturbances; see Fig. 2) which could only partially be considered in the categorisation system of Kenney and Doig (1986).

Histopathological findings considered in the categorisation system

(Partially) reversible findings

Endometritis: An endometritis was diagnosed in $49 \%$ of the biopsies. The occurrence of endometritis could not definitely be assessed in 3 samples due to widespread artefacts and every second endometrium did not show an endometritis. The inflammation was mostly (76\%) mild. A moderate and severe endometritis was diagnosed in $21 \%$ and $3 \%$ of the cases, respectively. According to the cellular composition (cellular character) most of the biopsies showed a non-suppurative (subclinical) endometritis (73\%). A mixed-cellular and suppurative inflammation was seen in $19 \%$ and $7 \%$, respectively. In contrast an eosinophilic and granulomatous endometritis was

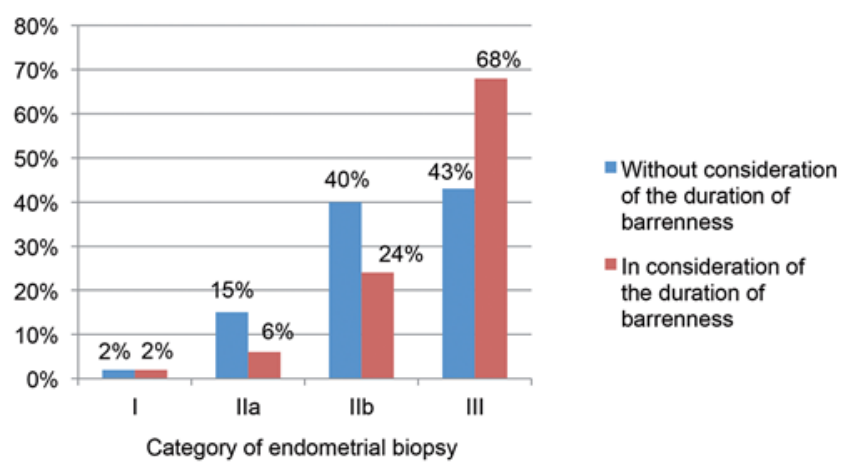

Fig. 1 Categorisation of the endometrial biopsies of old mares according to Kenney and Doig (1986) without consideration (blue bars) and in consideration (red bars) of the duration of barrenness Kategorisierung der Endometriumbioptate alter Stuten gemäß Kenney und Doig (1986) ohne (blave Balken) und mit (rote Balken) Berücksichtigung der Güstzeit 
rarely observed (3\% and $1 \%$, respectively). In some cases different forms of endometritis were detected in the same biopsy.

Irreversible findings

Endometrosis: Endometrosis was detected in almost all biopsies (97\%). Only 3\% of all biopsies showed no signs of endometrosis. Due to widespread artefacts the occurrence of endometrosis could not definitely be assessed in 3 samples. Moderate lesions dominated (60\%), a mild (27\%) or severe (12\%) endometrosis was less frequently observed. In $70 \%$ of the cases at least one endometrotic focus in the sample showed signs of epithelial degeneration (destructive endometrosis). The endometrosis was mostly inactive $(77 \%)$, mixed (22\%) and especially active forms (1\%) were less frequently detected. A stromal fibrosis was seen in only 5 samples.

Lymphatic lacunae: Lymphatic lacunae were not observed in any sample.

Reversibility debatable

Endometrial atrophy: No sample showed an endometrial atrophy.

Histopathological findings which are not considered in the categorisation system

Perivasculitis: A perivasculitis was diagnosed in $43 \%$ of all samples. The inflammation was predominantly mild (67\%) and non-suppurative (94\%). A moderate or severe perivasculitis was less frequently observed $(21 \%$ and $12 \%$, respectively). In most cases (73\%) more than one vessel was affected.

PAMC: In $58 \%$ of the samples periglandular accentuated mononuclear inflammatory cell infiltrates (PAMC) were detected which were mostly mild (53\%) or moderate (35\%).

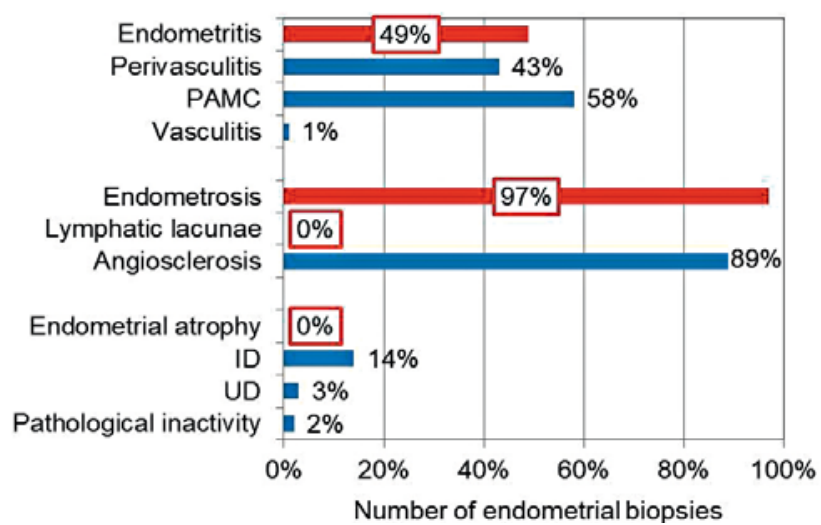

Fig. 2 Incidence of histopathological findings in the examined endometrial biopsies: histopathological alterations in red colour are considered in the categorisation system of Kenney and Doig (1986), whereas the alterations in blue colour are left out. PAMC: periglandular accentuated mononuclear inflammatory cell infiltrates; ID: irregular endometrial differentiation; UD: unequal endometrial differentiation | Inzidenz der histopathologischen Befunde in den untersuchten Endometriumbioptaten: histopathologische Alterationen in roter Farbe werden im Kategorisierungssystem von Kenney und Doig (1986) berücksichtigt, während die Alterationen in blaver Farbe nicht berücksichtigt werden. PAMC: periglandulär akzentuierte mononukleäre Entzündungszellinfiltrate; ID: irreguläre glanduläre Differenzierung; UD: ungleichmäßige glanduläre Differenzierung
Vasculitis: In 9 samples (1\%) a vasculitis was diagnosed.

Angiosclerosis:_Angiosclerosis was detected in $89 \%$ of all samples by routine examination (H.E.). Only in 66 specimens (8\%) no degenerative lesions of blood vessels were seen. In $3 \%$ of the samples this finding could not definitely be assessed. The lesions were generally classified as moderate $(45 \%)$ or severe (37\%), only $18 \%$ exhibited mild angiosclerosis. In the subsequent assessment of the 66 biopsies without angiosclerosis (in H.E. stained slides) by Picro-Sirius Red stain degenerative lesions of blood vessels were detected in nearly all biopsies.

Functional disturbances: $16 \%$ of all biopsies showed at least one type of endometrial maldifferentiation. An irregular endometrial differentiation was observed in $14 \%$ of all samples and represented the most frequent manifestation of maldifferentiation. In contrast, unequal endometrial differentiation and endometrial inactivity during the breeding season were detected only in $3 \%$ and $2 \%$ of all cases, respectively. During the breeding season (01/05-31/08, definition according to Killisch et al. 2014) 17\% of all samples showed an endometrial maldifferentiation (ID: 11\%; UD: 4\%; endometrial inactivity: $2 \%$ ).

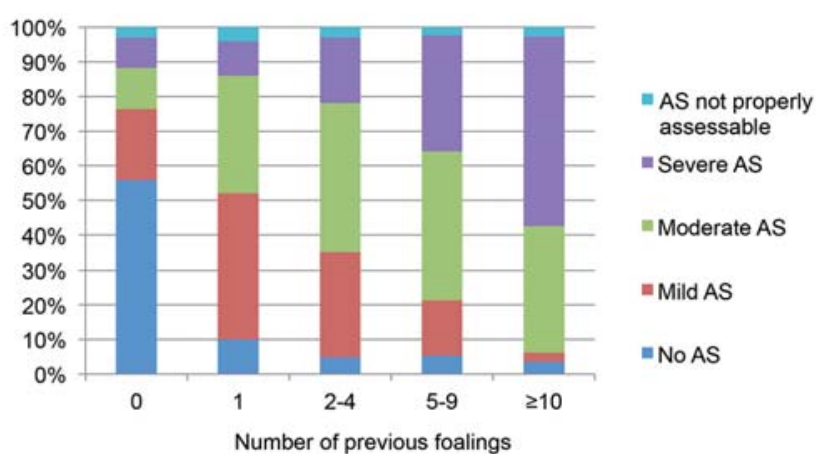

Fig. 3 Association between parity of the mare and incidence and degree of angiosclerosis (AS) | Zusammenhang zwischen Parität der Stute und der Inzidenz von Angiosklerosen (AS) und deren gradueller Ausprägung

Table 1 Categorisation of endometrial biopsies without consideration of the duration of barrenness: influencing factor age of the mare (own results and references) | Kategorisierung der Endometriumbioptate ohne Berücksichtigung der Güstzeit: Einflussfaktor Stutenalter (eigene Ergebnisse und Literaturangaben)

\begin{tabular}{|c|c|c|c|c|c|}
\hline \multirow{2}{*}{$\begin{array}{c}\text { Age of mares } \\
\text { in years }\end{array}$} & \multicolumn{4}{|c|}{ Number of endometrial biopsies } & \multirow{2}{*}{ Source } \\
\hline & I & $\| \mathrm{a}$ & $11 \mathrm{~b}$ & III & \\
\hline $25-32$ & $4 \%$ & $4 \%$ & $41 \%$ & $52 \%$ & \multirow{2}{*}{ Own results } \\
\hline $20-24$ & $2 \%$ & $15 \%$ & $40 \%$ & $43 \%$ & \\
\hline$>20$ & $2 \%$ & $13 \%$ & $37 \%$ & $48 \%$ & \multirow{2}{*}{$\begin{array}{l}\text { Schilling } \\
(2017)\end{array}$} \\
\hline $1-5$ & $43 \%$ & $36 \%$ & $17 \%$ & $3 \%$ & \\
\hline $17-24$ & $7 \%$ & $29 \%$ & $50 \%$ & $14 \%$ & \multirow{2}{*}{$\begin{array}{l}\text { Brinsko et } \\
\text { al. (1994) }\end{array}$} \\
\hline $2-7$ & $32 \%$ & $63 \%$ & $5 \%$ & $0 \%$ & \\
\hline$\geq 12$ & $31 \%$ & $40 \%$ & $26 \%$ & $3 \%$ & \multirow{2}{*}{$\begin{array}{l}\text { Waelchli } \\
\text { (1990) }\end{array}$} \\
\hline$\leq 11$ & $70 \%$ & $21 \%$ & $4 \%$ & $5 \%$ & \\
\hline
\end{tabular}


Influencing factor: age

Older mares ( $\geq 25$ years) were more frequently assigned to the prognostic unfavourable category III and less often to category lla than mares in their early twenties (see Table 1, differences not statistically significant, $\mathrm{p}=0.08$ ).

A statistically significant correlation between the age of the mares and the incidence and degree $(p=0.199)$ or quality $(p=0.26)$ of endometrosis was not detected. However, the following tendencies were observed: Older mares ( $\geq 25$ years) showed more frequently moderate to severe endometrosis and destructive forms of endometrosis than younger animals (see Table 2).

Functional disturbances were more often detected in the older age group $(24 \%)$ than in younger animals (16\%) although these differences were not statistically significant $(p=0.113)$. The incidence of perivasculitis did not differ between the two age groups $(p=0.968)$. There was no statistically significant association between the age of the mares and the incidence and degree of angiosclerosis $(p=0.439)$, endometritis $(p=0.490)$ and PAMC $(p=0.747)$.

\section{Influencing factor: parity}

There was no statistically significant correlation between parity of the mare and the categorisation of her endometrial biopsy without consideration of the duration of barrenness $(p=0.407$; nulli- and uniparous mares pooled).

Only a few biopsies did not show endometrosis independent of the number of foalings. Furthermore, there was no statistically significant association between parity and degree of endometrosis $(p=0.684)$. A statistically significant association between the number of previous foalings and incidence and degree of perivasculitis $(p=0.568), \operatorname{PAMC}(p=0.446)$ and endometritis $(p=0.759$, moderate and severe endometritis pooled) was not observed in this study. There was a statistically significant correlation between the occurrence of the functional disturbances and parity of a mare $(p=0.036) .35 \%$ of the nulliparous mares showed an endometrial maldifferentiation while the incidence in the other foaling groups varied between $12-16 \%$. Moreover, a statistically significant association was

Table 2 Characterisation of endometrosis: influencing factor age of the mare | Charakterisierung der Endometrose: Einflussfaktor Stutenalter

\begin{tabular}{|c|c|c|c|}
\hline \multirow{2}{*}{\multicolumn{2}{|c|}{$\begin{array}{l}\text { Characterisation } \\
\text { of endometrosis }\end{array}$}} & \multicolumn{2}{|c|}{ Number of endometrial biopsies } \\
\hline & & Age of the mares & Age of the mares \\
\hline \multirow{4}{*}{ Quantity } & No & $3 \%$ & $4 \%$ \\
\hline & Mild & $27 \%$ & $15 \%$ \\
\hline & Moderate & $58 \%$ & $65 \%$ \\
\hline & Severe & $12 \%$ & $17 \%$ \\
\hline \multirow{2}{*}{ Quality } & Nondestructive & $31 \%$ & $23 \%$ \\
\hline & Destructive & $69 \%$ & $77 \%$ \\
\hline
\end{tabular}

detected between the parity of the mare and the incidence and degree of angiosclerosis ( $p=0.001$; see Fig. 3). More than half of all nulliparous mares showed no degenerative lesions of blood vessels. However, severe angiosclerosis was also seen in these mares. Despite these quantitative distinctions there were also qualitative differences in angiosclerosis detected by Picro-Sirius Red stain. The vessels of nulliparous mares had only very mild lesions within the intima and the media while the adventitia was partially marked altered. In contrast, even uniparous animals had generally marked alterations within the intima and the media. Nulliparous mares predominantly showed a fibrosis/fibroelastosis and it seemed that the amount of elastic fibers increased with the number of foalings. In mares with at least 10 offspring the lesions of the vascular wall predominantly consisted of elastic fibers.

Special anamnestic characteristics of the examined geriatric mares

The comprehensiveness of anamnestic data was quite variable in the individual case. Many mares (39\%) showed pathological findings of the reproductive system in the clinical examination. These primarily included endometrial cysts (20\%), intrauterine fluid accumulations (12\%), and anatomical abnormalities (e.g. changes in the vulvar conformation, $14 \%$ ). $7 \%$ of all mares had exhibited aberrations of the cyclic activity, especially a missing cycle/oestrus and an irregular, prolonged or shortened cycle. However, these mares did not show functional disturbances more often than animals with a regular oestrus cycle. $13 \%$ of all mares had at least one embryonic/fetal loss in the past. Some animals (6\%) had given birth to a foal in the year of the examination. 14 animals were retired sport mares (partially maiden mares).

\section{Discussion}

The aim of the current study was the analysis and histomorphological characterisation of endometrial biopsies of old mares. Besides the age of the mare, the number of foalings also has an effect on the occurrence of endometrial alterations (Bracher et al. 1997a). A distinct differentiation between these two factors is almost impossible because a mare will always age during pregnancy.

The categorisation system of Kenney and Doig (1986) is an internationally accepted evaluation scheme to predict the ability of a mare to carry a foal to term (Schoon et al. 1992, Schoon and Schoon 2003, Aurich et al. 2011). There is a wide age range in each category (Doig et al. 1981, Ricketts and Alonso 1991). However, the age of a mare has a significant effect on the category to which she is assigned. As shown in Table 1, advanced age is associated with classification in prognostic unfavourable categories (Doig et al. 1981, Waelchli 1990, Ricketts and Alonso 1991, Brinsko et al. 1994, Kriesten 1995, Heilkenbrinker et al. 1997, Aurich et al. 2011, Schilling 2017). In the present study, the vast majority of examined endometria also belonged to categories IIb and III without consideration of the duration of barrenness or category III in consideration of the duration of barrenness. These results are comparable to the conclusions of Schilling (2017), whereas in the study of Brinsko et al. (1994) aged mares were mostly assigned to categories $\mathrm{Ila}$ and $\mathrm{Ilb}$ (see 
Table 1). These differences are likely explained by the different classification of the age groups. Furthermore, in this study, mares of the older age group were more frequently classified as category III mare than animals in their early twenties.

Old mares showed a variety of histopathological findings. However, some of these alterations are not considered in the categorisation system of Kenney and Doig (1986). The categorisation of old mares is particularly based on the occurrence of endometrosis which is a degenerative, irreversible and clinical silent disease (Bracher et al. 1997a, Schoon et al. 1997b, Aurich and Palm 2009). Endometrosis can only be detected by histopathological examination (Schoon et al. 1995, 1997b). Nearly all samples showed endometrosis which was mostly moderate. The incidence and the degree of endometrosis in this study were higher than in the investigations of Schoon et al. (1997b) and Schilling (2017) (see Table $3)$. These results confirm the assumption of endometrosis as an age-related disease (Doig et al. 1981, Ricketts and Alonso 1991, Brinsko et al. 1994, Schoon et al. 1994, Flores et al. 1995, Bracher et al. 1997b, Schoon et al. 1997b, Hoffmann 2006, Lehmann 2010, Aurich et al. 2011 ) and moreover, the degree of endometrosis increases with ageing (Schoon et al. 1995, Heilkenbrinker et al. 1997, Schilling 2017). The occurrence of endometrosis in infertile ("nulliparous") female mules (Huth et al. 2008, Jäger et al. 2008) is further indicative of an age-related pathogenesis which is independent of parity. The marked individual disparities in quantity of endometrosis in this and former studies (Doig et al. 1981, Ricketts and Alonso 1991) and the low incidence of severe forms in this study despite advanced age of the animals indicate that other factors than age, e.g. genetics (Schilling 2017), may play an important role in the pathogenesis of endometrosis. As shown, a correlation to the number of previous foalings does not exist (Schoon et al. 1994, 1995, Bracher et al. 1997b, Schoon et al. 1997b, Hoffmann 2006, Schilling 2017). Destructive forms of endometrosis which were frequently detected in this study are associated with a poor breeding prognosis (Schoon et al. 1997b, Lehmann et al. 2011).
Endometritis being part of the categorisation schema is a (partially) reversible lesion (Brunckhorst and Schoon 1990, Schoon et al. 1992, 1994, 1997b). The incidence of endometritis in old mares is higher than in the investigations of Schoon et al. (1997b) and Schilling (2017) (see Table 3). Endometritis occurs more often in older mares than in younger animals (Carnevale and Ginther 1992, Schilling 2017). The increased susceptibility of older mares to uterine infections may be caused by failure of natural uterine defensive mechanisms and/or inadequate physical clearance (McCue 1991). According to Schilling (2017) the parity of a mare has also an effect on the occurrence of endometritis and maiden mares are least often affected. Such a correlation could not be established in this study. This is likely to have been caused by the special fertility problems of old maiden mares. These mares are often susceptible to persistent breeding induced endometritis as a result of an abnormal tight cervix and consequential intrauterine fluid accumulations (Pycock 2003, Carnevale 2006).

Lymphatic lacunae and endometrial atrophy (part of the categorisation system) seem to play only a minor role in old mares (see Table 3). In contrast, histopathological findings which are not considered in the categorisation system and have a direct or at least an indirect impact on fertility prognosis are frequently diagnosed in old mares.

Most biopsies exhibited moderate to severe angiosclerosis. Incidence and degree of angiosclerosis in old mares is higher than in the studies of Schoon et al. (1997b) and Schilling (2017) (see Table 3). Degenerative angiopathies seem to have no direct but an indirect negative effect on fertility of the mare (Schoon et al. 1997a, 1999a, Schoon and Schoon 2003). The alterations are closely related to endometrosis and result in a decreased endometrial perfusion and drainage (Schoon et al. 1997a, 1999a, Schoon and Schoon 2003). Blaich et al. (1999) demonstrated by Doppler sonography that a marked fibrosis in the A. uterina is associated with an enhanced vascular resistance. Furthermore, endometrial angiopathies have

Table 3 Incidence and degree of different histopathological lesions: own results and references | Inzidenz und Ausprägungsgrad der unterschiedlichen histopathologischen Befunde: eigene Ergebnisse und Literaturangaben

\begin{tabular}{|c|c|c|c|}
\hline \multirow[b]{2}{*}{ Histopathological lesion } & \multicolumn{3}{|c|}{ Incidence of the histopathological lesion (predominant degree) } \\
\hline & Own results & $\begin{array}{c}\text { Schoon et al. (1997b) } \\
n=2500\end{array}$ & $\begin{array}{l}\text { Schilling (2017) } \\
\quad \mathrm{n}=11698\end{array}$ \\
\hline Endometrosis & $97 \%(++)$ & $60 \%(+)$ & $76 \%(+)$ \\
\hline Endometritis & $49 \%(+)$ & $35 \%$ & $\begin{array}{c}38 \text { or } 46 \% \text { (without or in consideration } \\
\text { of inflammatory cell infiltrates; }+ \text { ) }\end{array}$ \\
\hline Lymphatic lacunae & $0 \%$ & $3 \%$ & - \\
\hline Angiosclerosis & $89 \%(++/+++)$ & $80 \%$ & $59 \%(+/++)$ \\
\hline Functional disturbances & $\begin{array}{c}\text { Breeding season: } 17 \% \\
\text { - ID: } 11 \% \\
\text { - UD: } 4 \% \\
\text { - endometrial inactivity: } 2 \% \\
\text { - endometrial atrophy: } 0 \%\end{array}$ & $\begin{array}{c}\text { Whole year: ca. 13-14\% } \\
\text { - endometrial atrophy: ca. 3-4\% }\end{array}$ & $\begin{array}{l}\text { Breeding season: } 18 \% \\
\text { - UD and/or ID: } 16 \% \\
\text { - endometrial inactivity: } 1 \% \\
\text { - endometrial atrophy: } 1 \%\end{array}$ \\
\hline Perivasculitis & $43 \%(+)$ & $40 \%$ & \\
\hline
\end{tabular}

+: mild; ++ : moderate; +++ : severe; n: number of endometrial biopsies; ID: irregular endometrial differentiation; UD: unequal endometrial differentiation +: geringgradig; ++: mittelgradig; +++: hochgradig; n: Anzahl untersuchter Endometriumbioptate; ID: irreguläre glanduläre Differenzierung; UD: ungleichmäßige glanduläre Differenzierung 
a negative effect on fetal placental development (Kersten 2000, Schoon and Schoon 2003). Mares suffering from angiosclerosis have a lower density and branching of the chorionic villi (Kersten 2000). At least two factors, age and parity, have to be considered as causes of angiosclerosis (Schoon et al. 1997a, 1999a, Schoon and Schoon 2003, Schilling 2017 ) with parity having the greater influence (Kriesten 1995, Schoon et al. 1997a, 1997b, 1999a, Wrede 1999, Schilling 2017). Accordingly, even in old mares a correlation between incidence and degree of angiosclerosis and the number of previous foalings was observed. Old nulliparous mares often showed, as already described by Kriesten (1995), Schoon et al. (1997b) and Grüninger et al. (1998), an angiosclerosis especially affecting the adventitia. This can be interpreted as a predominantly age-related finding (Grüninger et al. 1998). Infertile ("nulliparous") female mules also exhibit angiosclerosis relating to aging (Jäger 2009). In multiparous animals the alterations affect all layers of the vascular wall and resemble the pregnancy sclerosis in other species (Schoon et al. 1997b, Grüninger et al. 1998, Schoon and Schoon 2003). Older multiparous mares with marked angiosclerosis diagnosed in endometrial biopsies can be identified as risk patients for fatal ruptures of extrauterine vessels during late pregnancy or birth (Ludwig et al. 2001). Some uni-/oligoparous mares in this study showed marked angiosclerosis affecting all layers of the vascular wall and therefore these mares could be risk patients as well. With regard to the age-related declining regeneration capacity of blood vessels (Kriesten 1995, Schoon et al. 1997a) the age of the mare at the time of the last pregnancy could play an important role in this context.

Functional disturbances may lead to permanent or temporary infertility depending on the individual cause (Schoon et al. 1999b, Schoon and Schoon 2003, Ellenberger et al. 2005). Their prognostic significance during winter anoestrus (Aupperle et al. 2003) and transition periods (Killisch et al. 2017) is questionable whereas they are an important finding with impact on the fertility of the mare in the breeding season. There is no association between the occurrence of functional disturbances and the age of the mare (Schoon et al. 1999b, 2000, Schilling 2017). The incidence of functional disturbances during the breeding season in this study is consistent with the incidence of these lesions in routine examinations (Schilling 2017) (see Table 3). Therefore, these alterations seem to be no special problem of old mares except of nulliparous ones. In accordance with Schilling (2017) nulliparous mares frequently showed functional disorders. Possible causes are hormonal treatments (Klug et al. 1997), recent retirement from sport (Kilgenstein et al. 2015) or long non-reproductive periods (Schilling 2017). The negative effect of long non-reproductive periods on fertility is described for nulliparous elephants and rhinoceroses. The prolonged exposure to endogenous sex steroids during these periods induces an asymmetric reproductive ageing with development of genital pathologies and erratic/absent luteal activity (Hermes et al. 2004, 2006).

Perivasculitis which mostly involved more than one vessel in one biopsy and PAMC were also common findings in endometrial biopsies of old mares. In case of multifocal perivasculitis a significant negative effect on fertility is detectable, even in biopsies without any other lesions (Kriesten 1995, Schoon and Schoon 2003). In contrast, the significance of PAMC is still unknown (Klose 2015, Klose and Schoon 2016).

The endometrium of old mares predominantly exhibits a mixture of alterations: mostly marked degenerative lesions, predominantly mild inflammatory processes and to lesser extent functional disturbances. Many of these findings are not considered in the categorisation system of Kenney and Doig (1986) but have to be regarded as important factors contributing to reduced fertility of old mares. Histopathological findings which were left out of the categorisation scheme so far (e.g. angiosclerosis), the quality and reversibility of lesions and as well as the age of a mare should be also considered for a precise prediction of a mare's reproductive potential (Schoon et al. 1997b, Schoon and Schoon 2003). Anamnestic data, especially the duration of barrenness, are furthermore important for prediction of the reproductive potential of an old mare. Many old mares had been barren for years and therefore have a poorer fertility prognosis according to the categorisation system of Kenney and Doig (1986). It is recommended to investigate endometrial biopsies of old mares before breeding, especially of animals whose reproduction potential is completely unknown (aged maiden mares and mares with the last foaling a long time ago), for different reasons: marked individual differences in degree of endometrosis and in occurrence of endometrial maldifferentiation, to diagnose and to treat reversible lesions for optimizing the breeding prognosis as well as to help the owner to determine whether breeding the mare is consistent with an acceptable risk.

\section{Acknowledgement}

The authors thank Ms Wipplinger and the histology laboratory of the Institute of Veterinary Pathology, University of Leipzig, for excellent technical support.

\section{References}

Aupperle H., Steiger K., Reischaver A., Schoon H.-A. (2003) UItrastructural and immunohistochemical characterization of the physiological and pathological inactivity of the equine endometrium. Pferdeheilkunde 19, 629-632; DOI 10.21836/ PEM20030611

Aurich C., Maric C., Aurich J. (2011) Zur morphologischen Interpretation von Endometriumbiopsien bei der Stute - eine retrospektive Studie. Pferdeheilkunde 27, 281-286; DOI 10.21836/ PEM20110313

Aurich C., Palm F. M. (2009) Erkrankungen von Vulva, Vagina, Zervix, Uterus und Eileiter. In: Reproduktionsmedizin beim Pferd: Gynäkologie - Andrologie - Geburtshilfe; 54 Tabellen, Ed.: Aurich C., 2nd ed. Parey, Stuttgart, 81-103

Blaich U., Petzold S., Bartmann C. P., Lorber K., Schoon H.-A., Raila G., Bollwein H. (1999) Doppler ultrasonographic studies of the uterine blood flow in mares. Pferdeheilkunde 15, 547-550; DOI 10.21836/PEM19990611

Bracher V., Gerstenberg C., Allen W. R. (1997a) Der Einfluss von Endometrose (degenerativer Endometriumserkrankungen) auf Fruchtbarkeit, Plazentation und fötale Entwicklung beim Pferd. Pferdeheilkunde 14, 465-473; DOI 10.21836/ PEM19970507

Bracher V., Gerstenberg C., Mathias S., Allen W. R. (1997b) Influence of age and parity on the equine endometrium. Pferdeheilkunde 13,549 
Brinsko S. P., Ball B. A., Miller P. G., Thomas P. G., Ellington J. E. (1994) In vitro development of day 2 embryos obtained from young, fertile mares and aged, subfertile mares. J. Reprod. Fertil. Suppl. 102, 371-378; DOI 10.1530/jrf.0.1020371

Brosnahan M. M., Paradis M. R. (2003) Demographic and clinical characteristics of geriatric horses: 467 cases (1989-1999). J. Am. Vet. Med. Assoc. 223, 93-98; DOI 10.2460/javma.2003.223.93

Brunckhorst D., Schoon D. (1990) Stellenwert der histologischen Untersuchung von Uterusbiopsien bei der Diagnose von Fertilitätsstörungen der Stute. In: Fachgruppe "Pferdekrankheiten" 11. Arbeitstagung, Ed.: Deutsche Veterinärmedizinische Gesellschaft e.V., 1990 Mar 8 u. 9, Wiesbaden, 181-189

Burns T. A. (2016) Effects of Common Equine Endocrine Diseases on Reproduction. Vet. Clin. North Am. Equine Pract. 32, 435-449; DOI 10.1016/i.cveq.2016.07.005

Carnevale E. M. (2006) Chapter 17: Reproductive Disorders. In: Equine geriatric medicine and surgery, Ed.: Bertone J., 1st ed. Saunders Elsevier, St. Louis, Mo, 193-200

Carnevale E. M., Ginther O. J. (1992) Relationships of age to uterine function and reproductive efficiency in mares. Theriogenology 37, 1101-1115; DOI 10.1016/0093-691X(92)90108-4

Cole F. L., Hodgson D. R., Reid S. W., Mellor D. J. (2005) Ownerreported equine health disorders: results of an Australia-wide postal survey. Aust. Vet. J. 83, 490-495; DOI 10.1111/j.17510813.2005.tb13301.x

Doig P. A., McKnight J. D., Miller R. B. (1981) The use of endometrial biopsy in the infertile mare. Can. Vet. J. 22, 72-76

Ellenberger C., Bartmann C. P., Klug E., Hoppen H.-O., Hoffmann C., Bazer F. W., Klug J., Allen W. R., Schoon D., Schoon H.-A. (2005) Immunohistochemical characterisation of equine endometrial maldifferentiation with special emphasis on uterine secretory proteins. In: Havemeyer Foundation Monograph Series No. 14: Proceedings of the 6th International Symposium on Equine Embryo Transfer, Eds.: Alvarenga M., Wade J. F. Proceedings of the 6th International Symposium on Equine Embryo Transfer, 04.-06.08.2004, Rio de Janeiro; Brasilien, 1st ed. R \&W Communications, Suffolk, UK, 13-15

Flores J. M., Rodríguez A., Sánchez J., Gómez-Cuétara C., Ramiro F. (1995) Endometrosis in Mares: Incidence of Histopathological Alterations. Reprod. Dom. Anim. 30, 61-65; DOI 10.1111/j.14390531. 1995.tb00606.x

Gindoff P. R., Jewelewicz R. (1986) Reproductive potential in the older woman. Fertil. Steril. 46, 989-1001; DOI 10.1016/S00150282(16)49869-9

Ginther O. J. (1992) Reproductive biology of the mare: Basic and applied aspects, 2nd ed. Equiservices, Cross Plains, Wisconsin

Gordon L. R., Sartin E. M. (1978) Endometrial biopsy as an aid to diagnosis and prognosis in equine infertility. J. Equine Med. Surg. 2, 328-336

Grüninger B. U., Schoon H.-A., Schoon D., Menger S., Klug E. (1998) Incidence and morphology of endometrial angiopathies in mares in relationship to age and parity. J. Comp. Pathol. 119, 293-309; DOI 10.1016/S0021-9975(98)80051-0

Heilkenbrinker T., Kossin C., Scherbarth R., Frerking H. (1997) Zur Überprüfung geeigneter anamnestischer und klinischer Parameter für eine Abfohlprognose unter Praxisbedingungen. Dłsch. Tierärztl. Wschr. 104, 313-316

Hermes R., Hildebrandt T. B., Walzer C., Göritz F., Patton M. L., Silinski S., Anderson M. J., Reid C. E., Wibbelt G., Tomasova K., Schwarzenberger F. (2006) The effect of long non-reproductive periods on the genital health in captive female white rhinoceroses (Ceratotherium simum simum, C.s. cottoni). Theriogenology 65, 1492-1515; DOI 10.1016/i.theriogenology.2005.09.002

Hermes R., Hildebrandt T. B., Göritz F. (2004) Reproductive problems directly attributable to long-term captivity-asymmetric reproductive aging. Anim. Reprod. Sci. 82-83, 49-60; DOI 10.1016/i.anireprosci.2004.05.015

Hoffmann C. (2006) Morphologisch-funktionelle Untersuchungen zur Pathogenese der equinen Endometrose unter besonderer Berücksichtigung endometrialer Proteine und Kohlenhydrate. Diss. Med. Vet. Leipzig
Horohov D. W., Kydd J. H., Hannant D. (2002) The effect of aging on T cell responses in the horse. Dev. Comp. Immunol. 26, 121-128; DOI 10.1016/S0145-305X(01)00027-1

Huth H., Ellenberger C., Bartmann C. P., Rass J., Hoppen H.-O., Schoon H.-A. (2008) Morphologische und immunhistologische Untersuchungen an Endometriumbioptaten von Maultierstuten. Pferdeheilkunde 24, 38-43; DOI 10.21836/PEM20080109

Ireland J. L., Clegg P. D., McGowan C. M., McKane S. A., Pinchbeck G. L. (2011) A cross-sectional study of geriatric horses in the United Kingdom. Part 1: Demographics and management practices. Equine Vet J 43, 30-36; DOI 10.1111/i.20423306.2010.00145.x

Jäger K. (2009) Morphologisch-funktionelle Untersuchungen am Endometrium von Maultierstuten während des Sexualzyklus und nach Progestagen-Langzeitapplikationen. Diss. Med. Vet. Leipzig

Jäger K., Ellenberger C., Bartmann C. P., Rass J., Bazer F. W., Klug J., Allen W. R., Hoppen H.-O., Hoffmann C., Schoon H.-A. (2008) Histopathologische und immunhistologische Untersuchungen zum Sexualzyklus weiblicher Maultiere und zu den Auswirkungen einer Regumate ${ }^{\circledR}$-Langzeitapplikation. Pferdeheilkunde 24, 44-52; DOI 10.21836/PEM20080110

Kenney R. M., Doig P. A. (1986) Equine Endometrial Biopsy. In: Current Therapy in Theriogenology, Ed.: Morrow D. A., 2nd ed. Saunders, Philadelphia, 723-729

Kersten F. (2000) Klinische, histologische und zytologische Untersuchungen im Puerperium der Stute sowie ein Beitrag zur Gynäkopathologie unter besonderer Berücksichtigung der Placenta fetalis. Diss. Med. Vet. Leipzig

Kilgenstein H. J., Schöniger S., Schoon D., Schoon H.-A. (2015) Microscopic examination of endometrial biopsies of retired sports mares: An explanation for the clinically observed subfertility? Res. Vet. Sci. 99, 171-179; DOI 10.1016/j.rvsc.2015.01.005.

Killisch R., Böttcher D., Theuß T., Edzards H., Martinsson G., Einspanier A., Gottschalk J., Schoon H.-A. (2017) Seasonal or pathological findings? Morphofunctional characteristics of the equine endometrium during the autumn and spring transition. Reprod. Dom. Anim., 1-8; DOl 10.1111/rda.13016

Killisch R., Böttcher D., Theuß T., Edzards H., Martinsson G., Gottschalk J., Schoon H.-A. (2014) The equine endometrium during spring and autumn transition - a morphofunctional characterization. Reprod. Dom. Anim. 49, 46

King M. (1999) Breeding the Older Mare. https://thehorse. com/14528/breeding-the-older-mare/

Klose K. (2015) Endometriale periglandulär akzentuierte mononukleäre Entzündungszellinfiltrate beim Pferd: Physiologischer Befund oder Initialstadium einer Endometrose? Diss. Med. Vet. Leipzig

Klose K., Schoon H.-A. (2016) Periglandular inflammatory cells in the endometrium of the mare - A physiological defence mechanism which impacts on the development of endometrosis? Pferdeheilkunde 32, 15-23; DOI 10.21836/PEM20160102

Klug E., Bartmann C. P., Schöning A., Schoon D., Schoon H.-A. (1997) Auswirkung einer Progestagen-Langzeit-Applikation auf Sexualzyklus und Endometrium des Pferdes - Zwei Seiten einer therapeutischen Medaille. Pferdeheilkunde 13, 490-498; DOI 10.21836/PEM19970511

Kriesten H. (1995) Zur prognostischen Bedeutung von Angiopathien im Rahmen der Kategorisierung von Endometriumbiopsien bei der Stute. Diss. Med. Vet. Hannover

Lehmann J. (2010) Morphologisch-funktionelle Untersuchungen zur prognostischen Bewertung der equinen Endometrose. Diss. Med. Vet. Leipzig

Lehmann J., Ellenberger C., Hoffmann C., Bazer F. W., Klug J., Allen W. R., Sieme H., Schoon H.-A. (2011) Morpho-functional studies regarding the fertility prognosis of mares suffering from equine endometrosis. Theriogenology 76, 1326-1336; DOI 10.1016/i. theriogenology.2011.06.001.

Ludwig S., Schoon D., Aupperle H., Reiswitz A. von, Schoon H.-A. (2001) Angiopathien in der Endometriumbiopsie bei der Stute Ein Marker auch für extrauterine Gefäßläsionen? Pferdeheilkunde 17,608-614; DOI 10.21836/PEM20010614 
McCue P. M. (1991) Breeding the older mare. J. Equine Vet. Sci. 11 , 316-318; DOI 10.1016/S0737-0806(06)81259-1

McGowan T. W., Pinchbeck G., Phillips C. J. C., Perkins N., Hodgson D. R., McGowan C. M. (2010a) A survey of aged horses in Queensland, Australia. Part 1: management and preventive health care. Aust. Vet. J. 88, 420-427; DOI 10.1111/j.17510813.2010.00637.x.

McGowan T. W., Pinchbeck G., Phillips C. J.C., Perkins N., Hodgson D. R., McGowan C. M. (2010b) A survey of aged horses in Queensland, Australia. Part 2: clinical signs and owners' perceptions of health and welfare. Aust. Vet. J. 88, 465-471; DOI 10.1111/j.1751-0813.2010.00638.x.

Mellor D. J., Love S., Gettinby G., Reid S. W. (1999) Demographic characteristics of the equine population of northern Britain. Vet. Rec. 145, 299-304; DOI 10.1136/vr.145.11.299

Pycock J. F. (2003) Breeding the Old Maiden Mare. https://www. equine-reproduction.com/articles/MaidenMare.shtml

Ricketts S. W., Alonso S. (1991) The effect of age and parity on the development of equine chronic endometrial disease. Equine Vet. J. 23, 189-192; DOI 10.1111/j.2042-3306.1991.tb02752.x

Schilling A. (2017) Die Endometriumbiopsie bei der Stute - eine Analyse der histologischen Befunde zwischen 1992-2012 am Leipziger Institut für Veterinär-Pathologie. Diss. Med. Vet. Leipzig

Schoon D., Grüninger B. U., Wrede S., Kriesten H., Menger S., Bartmann C. P. (1997a) Vascular lesions in the equine endometrium. Pferdeheilkunde 13, 546

Schoon D., Schoon H.-A., Klug E. (1999a) Angiosen im Endometrium der Stute - Pathogenese und klinische Korrelationen. Pferdeheilkunde 15, 541-546; DOI 10.21836/PEM19990610

Schoon H.-A., Schoon D. (2003) Die "Kategorie-I-Stute” nach Kenney und Doig - Abfohlwahrscheinlichkeit 80-90\%. Tatsache oder Fiktion? Pferdeheilkunde 19,698-701; DOI 10.21836/PEM20030626

Schoon H.-A., Schoon D., Klug E. (1994) Klinische Pathologie, Diagnostik und Terminologie endometrial bedingter Fertilitätsstörungen beim Pferd. In: DVG-Tagungsbericht, 13. Arbeitstagung der Fachgruppe Pferdekrankheiten, Ed.: Deutsche Veterinärmedizinische Gesellschaft e.V., 1994 Mar 24, Wiesbaden, 1-16

Schoon H.-A., Schoon D., Klug E. (1997b) Die Endometriumbiopsie bei der Stute im klinisch-gynäkologischen Kontext. Pferdeheilkunde 13,453-464; DOI 10.21836/PEM19970506

Schoon H.-A., Schoon D., Klug E. (1992) Uterusbiopsien als Hilfsmittel für Diagnose und Prognose von Fertilitätsstörungen der Stute. Pferdeheilkunde 8, 355-362; DOI 10.21836/PEM19920603

Schoon H.-A., Schoon D., Kötter B., Runge A., Klug E. (1995) Zu Pathogenese und Prognose der Endometrose der Stute. In: 21. Kongress der Deutschen Veterinärmedizinischen Gesellschaft e.V., Ed.: Deutsche Veterinärmedizinische Gesellschaft e.V., 1995 Mar 21, Bad Nauheim., 273-282

Schoon H.-A., Schoon D., Wiegandt I., Bartmann C. P., Aupperle H. (1999b) Endometriale Fehldifferenzierung - Eine klinisch relevante Diagnose in der equinen Reproduktionsmedizin? Pferdeheilkunde 15,555-559; DOI 10.21836/PEM19990613
Schoon H.-A., Wiegandt I., Schoon D., Aupperle H., Bartmann C. P. (2000) Functional disturbances in the endometrium of barren mares: a histological and immunohistological study. J. Reprod. Fertil. Suppl. 56, 381-391

Schoon H.-A., Wiegandt I., Schoon D., Aupperle H. and Klug E. (1997c) "Reading" endometrial biopsies in pathology: New approaches available? Pferdeheilkunde 13, 552

Scoggin C. F. (2015) Not just a number: effect of age on fertility, pregnancy and offspring vigour in thoroughbred brood-mares. Reprod. Fertil. Dev. 27, 872-879; DOI 10.1071/RD14390

Smith Thomas H. (2007) Breeding Challenges of Older Mares. https://thehorse.com/125268/breeding-challenges-of-oldermares/

te Velde E. R., Pearson P. L. (2002) The variability of female reproductive ageing. Hum. Reprod. Update 8, 141-154; DOI 10.1093/humupd/8.2.141

Traub-Dargatz J. L., Long. R. E., Bertone J. J. (2006) What Is an "Old Horse" and Its Recent Impact. In: Equine geriatric medicine and surgery, Ed.: Bertone J., 1 st ed. Saunders Elsevier, St. Louis, Mo, 1-4

USDA (2007) Equine 2005 Part II: Changes in the U.S. Equine Industry, 1998-2005. https://www.aphis.usda.gov/animal health/nahms/equine/downloads/equine05/Equine05_dr_Partl.pdf

USDA (2016) Equine 2015 Baseline Reference of Equine Health and Management in the United States, 2015. U.S. Department of Agriculture, APHIS. https://www.aphis.usda.gov/animal health/nahms/equine/downloads/equine 15/Eq2015 Rept1. pdf

Vanderwall D. K., Woods G. L., Freeman D. A., Weber J. A., Rock R. W., Tester D. F. (1993) Ovarian follicles, ovulations and progesterone concentrations in aged versus young mares. Theriogenology 40, 21-32; DOI 10.1016/0093691X(93)90338-6

Videan E. N., Fritz J., Heward C. B., Murphy J. (2008) Reproductive aging in female chimpanzees (Pan troglodytes). Interdiscip. Top. Gerontol. 36, 103-118; DOI 10.1159/000137688.

Waelchli R. O. (1990) Endometrial biopsy in mares under nonuniform breeding management conditions: Prognostic value and relationship with age. Can. Vet. J. 31, 379-384

Woodward E. M., Christoffersen M., Campos J., Squires E. L., Troedsson M. H. T. (2012) Susceptibility to persistent breeding-induced endometritis in the mare: relationship to endometrial biopsy score and age, and variations between seasons. Theriogenology 78, 495-501; DOI 10.1016/i.theriogenology.2012.02.028

Wrede S. (1999) Zur Pathogenese der Graviditätssklerose an endometrialen Gefäßen der Stute. Diss. Med. Vet. Leipzig 